DOI: https://doi.org/10.30837/MMP.2021.172

\title{
PROJECT-ORIENTED LEARNING IN THE CONDITIONS OF DIGITAL TRANSFORMATION
}

\author{
Molokanova V.
}

The article considers issues related to the implementation of project-oriented learning methodology in the context of the digital transformation of society. The problematic aspects of the implementation of project-oriented learning are revealed. It is highlighted that the human desire for self-realization can be successfully used in project-based learning. It is substantiated that project-oriented training requires systematic, step-by-step technology of development and implementation of projects instruments that are carried out in accordance with recognized rules and methods. The methodological bases of project-oriented learning of students and tools for assessing the management skills of future project managers are considered. An experimental study of the self-actualization of the project managers' personality in the process of mastering the tools of project management is presented. The result of the study is the deepening of the theoretical foundations of modern project-oriented learning in conditions of distance learning.

Keywords: project-oriented learning, personal development, talent realization, digital transformation of education.

\section{INTRODUCTION}

Problem formulation. The new millennium has witnessed the emergence numerous changes in educational processes as a result of information technology and the emergence of the concept of "knowledge economy", which examines the excellence of educational institutions in terms of talent in its human resources. The world scientific community has long questioned the feasibility of development, at the center of which is only material production. This necessitates a change in the general paradigm of human development from the ideology of accumulation of material wealth and competition for resources to the ideology of reasonable sufficiency and mutual assistance. In the process of implementing the new learning paradigm, project-oriented learning is very effective, allowing the most complete combination of academic knowledge with their practical application, as well as to 
develop the soft competencies of future managers. In addition, the technology of project-oriented learning serves as a tool for human self-development. At the same time, the widespread use of information and communication technologies in the educational process has led to the emergence of new components in the education system, which open wide opportunities for improving the educational process. The most important components are the use of distance learning courses, the formation of virtual communities of practitioners, the use of cloud technologies for collaboration, and much more. The digital transformation of education is an open way to change educational processes, models in order to develop and realize human abilities.

Analysis of recent researches and publications. Trends in global and national education are driving the growing importance of "soft management components" such as critical thinking, problem solving, collaboration, and various forms of communication that are created through a project approach $[1,2]$.

Analysis of recent research and publications. In 1984, David Kolb first proposed a model of step-by-step adult learning. The principle of Kolb's theory is that the "direct and concrete experience" of an adult is the basis for "observation and reflection." These "observations and reflections" are transformed into "abstract concepts" that provide a new content of active actions that can be "actively tested", which in turn gives a new experience, and then again in a circle.

One of the important tasks of project training can be considered the study of self-actualization and self-development of people throughout life, as well as the creation of mechanisms for integrating the practice of self-development of the manager in the processes of daily activities. The modern economy creates conditions when, in order to remain competitive, enterprises are interested in innovative projects that can be successfully implemented under the conditions of introducing creative approaches to solving the tasks [4]. Regarding human resource management, the project management methodology is focused on research, evaluation and development of leadership qualities of the project manager, and building effective teams at all levels of the organization [5]. However, most motivation tools are based 
on the premise that there is a contradiction between the group and individual motivation. This gives rise to the concept of mismatch of project implementation processes and self-realization of its employees, in addition, it is believed that the needs of managers are changing rapidly and they can not be predicted [6].

Psychological dictionaries, interpret this term quite ambiguously, different authors call the theory of self-actualization differently: self-actualization, selfrealization, integration, mental health, individualization, autonomy, creativity, productivity - but they all agree that all these are synonyms of realization of potentials of the individual, formation of the person in the full sense of the given word, namely formation of whom the person can really become [7].

One of the most common interpretations of the concept of "self-actualization" is revealed through the ability to become yourself [8]. However, for this, the individual must understand who he really is, get rid of illusions, complexes and develop creative abilities. [9].

The idea of self-actualization was conceptualized in the works of Kurt Goldstein. Man, according to Goldstein, is guided by the tendency to fully actualize the inherent opportunities, talents, "own nature" [10]. Goldstein linked the reproduction of the tendencies inherent in the individual to actualization with the inevitable conflict with the forces of the external environment. A normal and healthy organism, undergoing actualization, overcomes obstacles created by obstacles to the world. Goldstein identified the impossibility of self-realization as a major factor in mental illnesses.

Karl Rogers contains much in common with Goldstein's ideas in the concept of, "desire for self-actualization". Under the desire for self-actualization, Rogers defines "the desire for growth, development, the tendency to manifest and activate all the abilities of the organism to the extent that activation contributes to the development of the organism or personality" [11]. Rogers emphasized that selfrealization should be the goal of each individual; it is a direct pursuit of their own way, not following someone else's instructions. 
Thus, each person has his "true self", or inner essence - this is the authenticity, which is already sufficiently developed and understood by the individual. To achieve authenticity or self-actualization, according to K. Rogers, a person must activate his personality, living in harmony with his inner essence [11]. Those who have failed to achieve self-actualization become neurotic, ill, and devoid of authenticity.

The analysis showed that the current standards of project management do not give a holistic picture of the depth and potential of the project methodology as a tool for the value transformation of the world.

The objective of the article is studying of the actual problem related to the formation of the educational programs for masters in project management, taking into account the digital transformation of learning processes.

\section{METHODICAL MATERIALS OF THE STUDY}

In the conditions of accelerating processes of globalization and the development of technologies in modern education, there is a radical change in the purposes and tasks of training. Employers are not now concerned about the lack of knowledge acquired by students, as this knowledge changes every year and becomes obsolete before students can master it. They are much more concerned about the lack of specialists who are able to improve their knowledge and skills in various fields because this is what they will have to do all their conscious life [13]. In many areas, priority is given to project-oriented training, which is aimed at forming the activity competence of future professionals. Working in teams to develop complex projects, students develop skills of a higher order, as they have the opportunity to put their knowledge into practice. The most common contradiction of educational processes is the contradiction between the mass nature of education and the need for the individual development of the individual in the learning process. This contradiction has become the driving force of innovation processes in education. To resolve this contradiction, training based on the use of modern digital technologies is offered all over the world, which is becoming a key means of ensuring the free development of the individual. The huge flows of information that anyone can get from the Internet 
make education more accessible. Feedback between the teacher and students is carried out through the use of remote platforms, in order to individually assess the results achieved by students [14]. The use of digital applications allows you to quickly communicate with students and adjust their learning achievements automatically. The use of digital technologies also allows for the more productive implementation of project-oriented learning.

During the preparation of masters in the specialty 073 "Project Management" at the Project Management Department of Dnipropetrovs'k Regional Institute of Public Administration (DRIPA, Ukraine), the main provisions for the development of behavioral competences are taught within the discipline "Project management" [15]. The content of the theme "Self-management and activation of creative activity" includes the following topics: the role of personality in project management; selfmanagement and means of project manager constant development; the role of creative activity and methods of its activation; gaming and non-traditional methods of creative search. In the process of interactive learning, students have to determine their scope of project activity with certain extension and generate the main idea of their projects for the development of future master's work.

For future project managers, first of all, it is important correctly determine its propensity to a certain area of the project activity. In this regard, DRIPA paid considerable attention to the choice of the student future master's work theme. Since the first project always affects to the professional life of its developer and determines its future career growth. A properly selected project theme can be compared to connecting to a power plant that will best fit internal growth and the individual's goals realization. In such case, the task of the teacher is guiding of student, asking him the right questions, lead him to a sense of understanding his inner vocation. Here, the instructor should be an adviser and coach who is ready to listen and understand carefully, and not to demand answers or frighten with bad marks.

The choice of the theme of the master's work may related to the previous field of activity of the student. Nerveless, more often there are other cases when the student is interested in a new subject activity and chooses an appropriate theme, which in 
this case gives more opportunities to apply a creative approach. Correct wording of the topic of the master's theme is a responsible issue and indicates the level of knowledge and scientific culture of the student and its headmaster. Stages of the creative process of determining the topic of the future master's work is given on table 1.

Table 1

Stages of the creative process of determining the master's work theme

\begin{tabular}{|c|c|c|}
\hline \multirow{12}{*}{$\begin{array}{l}\text { Project Management } \\
\text { Methodology and } \\
\text { Logical-Structural } \\
\text { Analysis }\end{array}$} & \multirow{3}{*}{ Stage 1. Preparation } & 1.1. Intellectual-creative preparation \\
\hline & & 1.2. The manifestation of social needs \\
\hline & & 1.3. Choose an area of interest \\
\hline & \multirow{3}{*}{$\begin{array}{l}\text { Stage } 2 \text {. Formation of } \\
\text { the concept }\end{array}$} & 2.1. Collection and analysis of information \\
\hline & & 2.2. Define the purpose of the project \\
\hline & & 2.3. Directed search of means \\
\hline & \multirow{3}{*}{ Stage 3. Search phase } & 3.1. Free generation of ideas \\
\hline & & $\begin{array}{l}\text { 3.2. Formation of alternatives to achieve the } \\
\text { goal }\end{array}$ \\
\hline & & $\begin{array}{l}\text { 3.3. Select the optimal strategy for achieving } \\
\text { the goal }\end{array}$ \\
\hline & \multirow{3}{*}{$\begin{array}{l}\text { Stage 4. Detailed } \\
\text { Planning }\end{array}$} & $\begin{array}{l}\text { 4.1. Description of the general concept of the } \\
\text { project }\end{array}$ \\
\hline & & 4.2. Structuring the project \\
\hline & & 4.3. Detailed project planning \\
\hline
\end{tabular}

However, the most important results, according to the author, are that a person who has correctly defined the sphere of his interests becomes more active, striving for independent learning, capable of setting tasks for changing his behavior and performing them. Because of this awareness, self-management processes become effective and interesting for the individual. These features are the main prerequisite for the formation of leadership qualities and the ability to self-realization of project managers. The project manager's self-realization measure should be manifested in practical actions on the transformation of the environment through projects. Project 
based leaning (PBL) methods better prepare students for self-solution of project tasks, prevent social passivity and apathy that may occur outside the training room.

Thus, during master's work, students should demonstrate the skills of modern managerial thinking and system knowledge in project management, the ability to professional project activities that involves understanding their own potential in project management.

\section{RESULTS OF THE STUDY}

Based on DRIPA (Dnipro, Ukraine), an experimental study was carried out for the self-actualization of future project managers' personalities after studying the course "Project Management". Theoretical and practical classes on project tasks were selected so that students could demonstrate the full range of behavioral competencies, their ability to professional project activities, and their propensity to a particular subject area in the field of project management. Training took place remotely using the corporate platform G Suite, using software MS Project MS Teams.

Assessment of the formation of project skills in students was conducted based on behavioral competencies of project managers [16]. Competencies were taken from the list of behavioral competencies of the project manager according to IPMA and included the following qualities: self-government, personal integrity, personal communication, relationships and interaction, leadership, teamwork, conflicts and crises, ingenuity, negotiation, and results in orientation [16]. Based on the received data, personal profiles were constructed and the group profile of groups of students was calculated. In the study, the weights for all ten behavioral competencies of project managers were the same. The change in behavioral competencies of managers before and after training is shown in table 2 .

The analysis of obtained data suggests that after the training on the development of creative abilities, the desire of man to self-actualization is significantly increasing. Even considering that, the successful use of psychodiagnostic methods is directly dependent on the ability of the experimenter to 
form an adequate attitude to the person, and that any method of diagnostics has a degree of error, one can suppose that the study showed that the desire of man to selfactualization is an effective means of motivation the project activity. Based on personal aspiration for self-realization, it is possible to create effective tools for improving project teams. Nevertheless, the most important results, according to the author, are that a self-actualized person becomes more active, striving for independent learning, able to set tasks to change their own behavior and perform them.

Table 2

Change of group project competencies

\begin{tabular}{|l|c|c|c|}
\hline \multicolumn{1}{|c|}{ Competences } & $\begin{array}{c}\text { Percentage before } \\
\text { learning \% }\end{array}$ & $\begin{array}{c}\text { Percentage after } \\
\text { learning \% }\end{array}$ & $\begin{array}{c}\text { The difference in } \\
\text { \% }\end{array}$ \\
\hline Leadership & 65 & 86 & 21 \\
\hline Motivation & 41 & 59 & 25 \\
\hline Self-control & 48 & 83 & 51 \\
\hline Assertiveness & 37 & 81 & 48 \\
\hline Relaxation & 33 & 82 & 23 \\
\hline Openness & 28 & 67 & 24 \\
\hline Creativity & 44 & 36 & 25 \\
\hline Result orientation & 12 & 66 & 18 \\
\hline Efficiency & 41 & 81 & 14 \\
\hline Consultation & 28 & 73 & 18 \\
\hline Negotiation & 55 & 75 & 33 \\
\hline Conflicts \&crisis & 61 & 58 & 50 \\
\hline Reliability & 40 & 81 & 23 \\
\hline Values orientation & 48 & 88 & \\
\hline Ethics & 38 & & \\
\hline
\end{tabular}

As a result, the involvement of students in the educational process becomes effective and interesting for the individual. This feature is the main prerequisite for 
the quality and efficiency of higher forms of self-management and self-actualization, as the most important social features of the project manager.

The degree of self-realization of the project manager may be manifested in the nature and practical realization of projects. In this case, such individuals who have achieved managerial skill in motivating performers through their own self-realization should lead the activities of each of the personalities.

\section{CONCLUSIONS AND PERSPECTIVES OF FURTHER RESEARCH}

Based on the analysis of the results of the study, the following conclusions can be drawn.

1. The human desire for self-realization can be successfully used in projectoriented learning. At the same time, the development of creative abilities and selfactualization is an effective means of motivating project team members to achieve the overall goal of the project.

2. Skills of self-actualization and self-learning become one of the most important elements of behavioral competence of project managers. They help project managers quickly find their place in the job market. Because Ukraine is in a state of reform, project management as a means of implementing change remains a very relevant specialty.

3. Information learning technologies help distance-learning students to quickly develop basic competencies in digital literacy and find their direction for further improvement in the future field of activity.

In the future, the author plans to continue studying the possibility of integrating the practice of self-development of project managers in the activities of an organization that is constantly self-improving.

\section{REFERENCES}

1. Abramo, G., D’Angelo, A. and Carloni, M. (2019). The balance of knowledge flows. Scientometrics 13 (1): 1-9. https://doi.org/10.1016/j.joi.2018.11.001.

2. Framework for 21st century leaning. Retrieved from http://www.p21.org/our-work/p21framework. 
3. Kolb, D. A. and Fry, R. (1975) Toward an applied theory of experiential learning. Theories of Group Process, London: John Wiley.

4. Thomas, J. W. (2000). A review of research on PBL. http://www.bobpearlman.org/BestPractices/PBL.htm. (accessed 10.01.2018).

5. Voogt, J., \& Roblin, N. P. (2012). A comparative analysis of international frameworks for 21st century competences: Implications for national curriculum policies. Journal of Curriculum Studies, 44(3), 299-321.

6. Larregue, J., Lariviere, V. and Mongeon, P. (2020). On the institutional and intellectual division of labor in epigenetics research: A scientometric analysis. Social Science Information 59 (1): 117-43. https://doi.org/10.1177/0539018419898394.

7. Seminozhenko V. (2008). Ukraine - 2015: Don't lose your future. V Semynozhenko, V.Geets. Day. 24 Jan., 4-10.

8. Bushuyev, S.D., Bushuyeva, N.S. (2010). Mechanisms of formation of values in the activities of project-driven organizations. Eastern European Journal of advanced technologies. Vol. 1, № 2 (43), 4-9.

9. Leontyev D.A. (1997). An essay on the psychology of the individual. Moscow: Prosveshchenie, 164.

10. Psychological dictionary (1996). Ed. V.P. Zinchenko, B.G. Meshcheryakova. Moscow: Prosveshchenie, 440.

11. Buss, Allan R. A Dialectical Psychology (1989). New York: Irvington Publishers.

12. Vakhromov E.E. (1995). The concept of self-realization as the basis of humanistic pedagogy. // Problems of education in the work of postgraduate students. IPI RAO. M., P. 149-153.

13. . Rogers, Carl R. (1961) On Becoming a Person. Houghton Mifflin, 120.

14. Bravo, G., Farjam, M., Moreno, F., Birukou, A. and Squazzoni, F. (2018). Hidden connections: Network effects on editorial decisions in four computer science journals. Journal of Informetrics 12: 101-112. https://doi.org/10.1016/j.joi.2017.12.002

15. Work syllabus on discipline "Project management" (2020). Edited by V.M. Molokanova. Dnepr: DRIPA. 18.

16. Chen, K., Zhang, Y., and Fu, X. (2019). International research collaboration: An emerging domain of innovation studies?' Research Policy, 48 (1): 149-168. https://doi.org/10.1016/j.respol.2018.08.005

17. Individual Competence Baseline for Project, Programme \& Portfolio Management; 4th Version. (2015). International Project Management Association, 415. 